\title{
第171回 岡山外科会
}

\author{
日 時：平成 22 年 2 月 6 日（土） $13: 30 \sim$ \\ 場 所：川崎医科大学 現代医学教育博物館 3 階小講堂 \\ 会長: 宇野昌明
}

(平成 22 年 2 月 20 日受稿）

\section{1. 岡山大学乳癌治療・再建センターの現況}

岡山大学病院 形成外科 $\mathrm{a}$, 乳腺内分泌外科 ${ }^{\mathrm{b}}$

渡部聡子 ${ }^{\mathrm{a}}$, 大㭇祐 喜 ${ }^{\mathrm{a}}$, 佐 野成一 ${ }^{\mathrm{a}}$ 木股敬裕 ${ }^{\mathrm{a}}$ 枝園忠彦 ${ }^{\mathrm{b}}$, 元木崇之克 平成人 ${ }^{\mathrm{b}}$, 松岡順治 ${ }^{\mathrm{b}}$, 土井原博義 ${ }^{\mathrm{b}}$ 2007年10月より当院で一期的乳房再建術を開始し，2008 年 5 月より岡山大学乳がん治療・再建センター (Breast Cancer Treatment and Reconstruction center: 以下 BCTR）を正式に設立した。乳房再建症例は2007年10月〜 2009年 12 月で75症例（24～82歳 平均 47.0 歳）に及んでい る. BCTR 設立後の推移, 現在の取り組みや改善点等につ いて報告する。

\section{2. 当科における広背筋皮弁を用いた乳房再建の経験} 岡山大学病院 形成外科

佐野成一

乳癌における乳房切除後の再建には腹直筋や広背筋など の皮弁を用いる方法がある。広背筋皮弁は遊離皮弁と異な り，顕微鏡による血管吻合が不要であるため, 手術時間を 短縮でき一部の施設に限らず行なうことができ, 腹部に手 術の既往や挙児希望がある場合は第一選択となる。当科で は広背筋皮弁を用いた乳房再建を多数経験しており, 若干 の考察を加えて報告する。

\section{3 . 当科における深下腹壁動脈穿通枝皮弁を用いた乳 房再建の経験}

岡山大学病院 形成外科

田中義人，片山裕子，山口憲昭 大㭇祐喜, 安積昌吾, 佐野成一 小野田 聡, 渡部聡子, 山田潔 長谷川健二郎，難波祐三郎，木股敬 裕 当院では2007年10月から 2009年11月の 2 年 1 カ月の間に 乳癌切除後の乳房再建術を66例施行し, そのうち17例で深 下腹壁動脈穿通枝皮弁 (deep inferior epigastoric perforator flap：以下 DIEP flap）を用いて再建した. DIEP flap の挙
上の際に含めた穿通枝の位置と本数，皮弁の大きさとデザ イン, 術後合併症について, 若干の文献的考察を加え報告 する。

\section{DIEP 皮弁における術中 ICG 蛍光血管造影法の考 察}

岡山大学病院 形成外科

安積昌吾, 片山裕子, 大槻祐喜 佐野成一, 田中義人, 小野田 聡 渡辺聡子, 山田潔, 長谷川健二郎 難波祐三郎, 木股敬裕

遊離皮弁手術に扔ける穿通枝の同定は術前の手術のプラ ンニングに際し非常に重要である。乳房再建における腹直 筋穿通枝皮弁の術中に，ICG（indocyanine green）蛍光血 管造影法と赤外線カメラを用いて穿通枝の確認を試みた. 蛍光の描出のされ方が症例により異なっていた，その原因 について検討し, 考察してみた。

\section{THA cup 再置換術後に早期破綻した 1 例に対す る治療経験}

岡山大学大学院医歯薬学総合研究科 整形外科学 ${ }^{\mathrm{a}}$, 運動 器医療材料開発b

藤原智洋 ${ }^{\mathrm{a}}$, 遠藤裕介 ${ }^{\mathrm{a}}$, 三谷 茂 ${ }^{\mathrm{a}}$

尾嵉敏文 ${ }^{\mathrm{a}}$, 藤原一夫 ${ }^{\mathrm{b}}$

cup 再置換術の骨欠損に対し当院では人工骨と支持プレ ートを使用してきた。今回，早期破綻した 1 例を報告する. 61歳女性, 左変股症. 他院セメント cup THA 後 9 年で cup 緩み, AAOS 分類正を認めた。人工骨と KT plate で再置 換術を施行したが，術後 8 カ月時に転倒しKT plateの migration とフック破損を生じ, 同種骨とKT plate で再々 置換術を施行した。臼底部骨欠損では人工骨ごと migration を生じる症例があり，同種骨による IBG は充填が容易 でより早期の骨稜改変が期待できる. 


\section{MIS THA における Metal on Metal 摺動面を有す る大骨頭の使用経験}

岡山労災病院 整形外科

小野智毅, 難波良文, 門田弘明

寺田忠司，兒玉昌之，相賀礼子

花川志郎

【目的】 Metal on Metal (以下 MoM) 摺動面を有する大骨 頭を用いた MIS THAの短期成績ついて検討した。【対象 および方法】 $\mathrm{M}^{2} \mathrm{a}$-Magnum システム（Biomet 社）を用い て当科で施行されたMIS THA 55関節を対象とした。【結 果】JOA score は, 術前平均 39.2 点から退院時平均 67.2 点 に改善した。コンポーネントの緩み, 脱臼, 感染, 金属ア レルギーなどの合併症はなかった、【考察】大骨頭を用いた MoM は, 術後脱臼の減少, 可動域の増大, 低摩耗性によ る良好な長期成績が期待される.

\section{Centpillar stem で著明なゆるみを生じた 1 例}

岡山大学病院 整形外科

$$
\text { 長谷井 寋, 遠藤裕介, 鉄永智紀 }
$$$$
\text { 三谷茂，尾㟝敏文 }
$$

Centpillar stem（Stryker）は骨温存型 anatomical stem として開発されたが, 術中骨折や subsidence の問題が存在 し，その後改良された。今回旧型の Centpillar stem を使用 し術後 1 年で著明な subsidence と緩みをきたした 1 例に ついて報告する. 症例は54歳女性. 両変形性股関節症の患 者で右側 THA 術後であり, 今回は左側の THA を施行し た。

\section{NCB Distal Femur プレートによる大腿骨遠位部 骨折の治療経験}

岡山大学病院 整形外科

斎藤太一, 野田知之, 島村安則

中原龍一, 雑賀健多, 尾㟝敏文

Polyaxial locking を有する NCB Distal Femur プレート

（NCB DF）を用いた大腿骨遠位部骨折の治療成績につい て報告する５例でX線及び臨床成績を評価した。偽関節 や開放骨折例が多く遷延癒合傾向にあったが 4 例で骨癒合 し 1 例は経過観察中である. Alignment は良好に維持され ていた. TKA 周囲骨折や偽関節例などに対して NCB DF は，骨片の固定性獲得に優れ有用であった。

\section{Goldenhar syndrome に合併した側弯症の 1 例} 岡山大学病院 整形外科

塩崎泰之, 杉本佳久, 三澤治夫 高畑智宏, 田中雅人, 尾㠃敏文

Goldenhar syndromeに合併した側弯症に対して手術加 療を行ったので報告する。【症例】14歳女性. 主訴は，側弯 症に伴う歩行障害であった。側弯が進行し座位，立位とも にバランスが悪く歩行困難となり手術目的に入院となっ た。既往歴に goldenhar syndrome，心臟大血管転位症があ り Fontan 手術を施行している，身長 $137 \mathrm{~cm}$ 体重 $31 \mathrm{~kg}$ ，精 神発達遅滞を認めた。初診時単純レントゲンで Cobb 角 $58^{\circ}$ の側弯を認め, 1 年の経過で $76^{\circ}$ に進行していた。手術は, T 4-L 3 の後方固定術を行った. 周術期は心不全を認め ICU 管理となった。術後Cobb 角は $26^{\circ}$ （矯正率 $65 \%$ ）とな った．立位バランスも改善し歩行は安定した.【考察】 goldenhar syndrome に伴う春椎異常としては, 半椎, 二分 春椎，側弯，癒合椎等の報告があるままた，先天性心疾患 の合併を $47 \%$ に合併すると報告されており，本疾患患者の 手術時は厳格な周術期管理が必要となる。

\section{0. 多発性筋内内脂肪腫の 1 例}

川崎医科大学 整形外科

大 成 和 寞, 長谷川 徹, 三 河 義弘 【症例】60歳，女性．MRIにて左後頚部，左背部，右大腿 部に脂肪腫を認めた，摘出術を行ったところ，後碩部と大 腿部の脂肪腫は筋肉内に存在し，それぞれ筋肉内脂肪腫と 診断された。背部の脂肪腫は通常の皮下脂肪腫と診断され た.【考察】筋肉内脂肪腫は稀で，1個体に多発する症例は 本邦ではこれまでに報告例はない。筋肉内脂肪腫は再発率 が通常の脂肪腫より高率とされているが，現在，再発を認 めていない.

\section{1. 大腿骨頭外骨腫にともなう変形性股関節症の 1 例}

岡山大学大学院医歯薬学総合研究科 整形外科学 ${ }^{\mathrm{a}}$, 運動 器医療材料開発b

金澤智子 ${ }^{\mathrm{a}}$, 藤原一夫 ( $^{\mathrm{b}}$ 三谷 茂 遠藤裕介 ${ }^{\mathrm{a}}$, 尾﨑敏 文 $^{\mathrm{a}}$

比較的まれな大腿骨頭発生の外骨腫により変形性股関節 症に至った 1 例を経験したので報告する。症例は47歳男性. 前医にて右大腿骨頭の外骨腫による股関節変形を指摘され た．保存的加療の後に変形の増悪を認め, 加療目的で当科 紹介となった。右人工股関節置換術を施行し経過良好であ る。本症例は股関節内に発生した単発性の外骨腫であり, そのために関節不適合が生じ変形性股関節症に至ったと考 えられた。 


\section{2. 内反小趾に対する中足骨骨幹部骨切り術の治療経 験}

笠岡市立市民病院 整形外科

大澤誠也

内反小趾に対して中足骨骨幹部骨切り術を施行したので 報告する。症例は62歳, 女性, 右前足部の痛みと有痛性の 胼胝を認める. 術前 MTP-5 角 30 度, IMA4-5 角 15 度, 日 本足の外科学会 $2 \sim 5$ 趾判定基準（JSSF score）は32点で あった。手術は中足骨骨幹部で斜め骨切りを行い矯正した 後に k-wire を用いて固定した. 術後 MTP-5 角 3 度, IMA4 -5 角 5 度, JSSF score 85点であった。術後 6 力月現在良好 な骨癒合得られている。

\section{3. 脾破裂による腹腔内出血を呈した膵尾部癌脾浸潤 の一例}

津山中央病院 外科

中原健太, 山田隆年, 青山克幸 渡邊めぐみ, 吉田一博, 水野憲 治 松村年久, 野中泰幸, 林同輔 宮島孝直，黒瀬通弘，徳田直彦

患者は70歳女性. 眼前暗黑感, 冷汗を主訴に当院救急外 来受診。血液検査にて貧血を認め, 腹部 $\mathrm{C} T$ 検查にて脾臟 内に不整形の腫瘍および腹腔内出血を疑う所見あり，緊急 開腹術となった．膵尾部, 脾が一塊となった腫瘍を形成し て抢り, 脾臓の上極の破裂部より出血していた。摘出標本 の病理組織検査結果は膵尾部に発生し, 脾臓に浸潤する中 分化型腺癌であった。脾腫瘍の鑑別に膵尾部腫瘍の脾浸潤 も念頭に置くことが必要と考えられた。

\section{4. 異物を核とした胆管結石症例の検討}

岡山市立市民病院 外科

石川隆，渡部祥子，西村守 寺本淳, 川崎伸弘, 庄賀一彦 光岡晋太郎, 羽井佐 実, 松 前 大 濱田英明

現在, 腹腔鏡下胆囊摘出術は各種胆道疾患の標準術式で あるが，その症例数の増加とともに，手術時に使用する endoclip の迷入による合併症の報告も増加傾向にある. 今 回我々は，約10年前に胆霊摘出術（鏡視下手術から開腹手 術にコンバート）を受けた50代後半の男性が右悸肋部痛に て発症し，精査にて過去の手術時に使用した clip を核とし た胆管結石と判明した症例を経験したので若干の考察を加 えて報告をする。

\section{SILS ポートを用いた単孔式腹腔鏡下胆囊摘出術} 倉敷成人病センター 外科

中山文夫，飽浦良和，松本剛 昌 村嶋信尚, 仁科拓也, 山野武寿 池田義博

当科におけるSILS ポートを用いた単孔式腹腔鏡下胆囊 摘出術につき報告する。臍に $2.5 \mathrm{~cm}$ の皮切をおき SILS ポー 卜を挿入. SILS ポートに $5 \mathrm{~mm}$ ポート 3 本を挿入. $5 \mathrm{~mm} 30$ 度 斜視鏡を挿入。ループリトラクタで胆襄を挙上. 胆囊管, 胆囊動脈周囲の剥離はロティキュレーターカンシを用いた Cross-Hand 法で行う. 5 mmエンドクリップを用いて切離. 肝床部より胆囊を剥離し SILS ポートを外して臍から摘 出. 以上画像を交えて報告する.

\section{6. 消化管出血にて発症した胸腺癌小腸転移の 1 例} 津山中央病院 外科

有吉勇一, 中原健太, 青山克幸 渡邊めぐみ, 吉田一博, 水野憲 治 松村年久, 山田隆年, 野中泰幸 林同輔, 宮島孝直, 黒瀬通弘 徳田直彦

症例は83歳男性.78歳時に胸腺癌（中分化扁平上皮癌, Stage III) で手術されている. 黒色便・意識消失発作にて救 急入院し，ダブルバルン内視鏡にて回腸潰瘍からの出血を 認め, 内視鏡的止血術を施行した。 その後も出血再発し, 手術施行したところ回腸に $\phi 15 \mathrm{~mm}$ の腫瘤を認め小腸部分切 除術を施行した。病理にて胸腺扁平上皮癌の転移と診断さ れた，胸腺癌の小腸転移は非常に稀であり，若干の文献的 考察を加えて報告する。

\section{7. 回腸您室穿通による腸間膜膿瘍の 1 例}

川崎医科大学附属川崎病院 外科

薬師寺 宏, 木下真一郎, 林 次 郎 吉田和弘，森田一郎

症例は63歳, 男性, 右下腹部痛を主訴に救急外来受診, 血液検查データーで炎症所見上昇あり，腹部 CT で回腸末 端部に膿瘍形成認め，翌日に緊急手術施行，病理結果にて 回腸㰾室穿通による腸間膜膿瘍と診断であった。術後経過 良好であり16日目に退院となる. Meckel 毠室を除くと小腸 憩室の頻度は少なく, 回腸憩室は非常に稀な疾患である. 今回我々は回腸息室穿通による腸間膜膿瘍の 1 例を経験し たので若干の文献的考察を加え報告する. 


\section{8. 虫垂想室穿孔の 1 例}

国立病院機構岡山医療センター 外科

長 岡知里, 秋山一郎, 市原周 治 森秀暁, 國末浩範, 太田徹哉 藤原拓造, 臼井由行, 田中信一郎 野村修一

症例は62歳女性. 右下腹部痛を主訴に救急車にて搬送さ れた。腹部 CT にて虫垂腫大と周囲脂肪織濃度の上昇, 限 局性のフリーエアーを認めたため, 穿孔性虫垂炎と診断し 緊急開腹術を行ったところ虫垂媳室を 2 箇所認め, 虫垂間 膜側の 1 つが穿孔していた。病理診断では真性㮩室で虫垂 粘膜は蜂窩織炎性虫垂炎であった。虫垂慗室炎は稀な疾患 で術前診断は困難である. 発症年齢は虫垂炎よりも高く, 穿孔率は22〜66\%と高率である。

\section{9. 消化管異物による腸閉塞 2 例の経験}

川崎医科大学 消化器外科

安永＼cjkstart雅，窪田寿子，浦上＼cjkstart淳 岡保夫, 山下和城, 平井敏弘 消化管異物による腸閉塞を 2 例経験したので, 若干の文 献的考察を加え報告する.【症例 1 】 81 歳女性. 嘔吐を主訴 に当院入院した．繰り返す腸閉塞のため手術となった。手 術所見では回腸に異物を認めた。【症例 2 】64歳女性. 腹痛 を主訴に当院入院した. US と CT で回腸に異物を認めた。 イレウス管挿入で症状改善したが, 異物の移動はなく手術 となった。手術所見では回腸に異物を認めた。

\section{0. 保存的加療にて軽快した腸管気腫症の一例}

岡山大学大学院医歯薬学総合研究科 消化器 - 腫瘍外科学

藤原裕子, 田邊俊介, 白川靖博 近藤喜太, 野間和広, 宇野太 永坂岳司, 香川俊輔, 山辻知樹 貞森裕, 小林直哉, 藤原俊義 八木孝仁, 猶本良夫

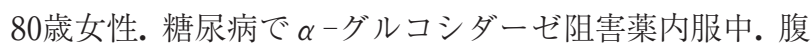
部膨満感にて近医受診. 穿孔性腹膜炎疑いで当科受診. 腹 部膨満及び皮下気腫を認めるも，腹膜刺激症状なし．血液 検查上明らかな異常なく, CT で結腸の著明なガス貯留と 右横隔膜下の free air を認め, 腸管気腫症の破裂による腹 腔内 free air と考えた。腹膜炎症状がなかったため保存的 加療とし, 症状 - 画像所見は改善. 今回我々は保存的加療 を行った腸管気腫症を経験したので文献的考察を加え報告 する。

\section{1. 当科における器械吻合による幽門側胃切除術の手 術手技と成績}

倉敷成人病センター 外科

池田義博, 中山文夫, 山野武寿

仁科拓也, 村嶋信尚, 松本剛昌

飽 浦良和

【目的】自動縫合器を使用した幽門側胃切除術の手術手技 と成績を報告する.【方法】2008年 1 月から現在までの当科 における幽門側胃切除術のうち，自動縫合器を使用した症 例と使用していない症例を比較検討した.【成績】手術時 間，出血量，経口摂取までの時間，退院までの時間および 合併症を比較し従来の手縫いに比べ，自動縫合器を用いた 手術手技の優位性が確認された。

\section{2. 当科における食道熄室手術症例の報告}

岡山大学大学院医歯薬学総合研究科 消化器 - 腫瘍外科 学 ${ }^{\mathrm{a}}$, 岡山市立市民病院 外科 ${ }^{\mathrm{b}}$

田辺俊介 ${ }^{\mathrm{a}}$, 藤原裕子 ${ }^{\mathrm{a}}$, 近藤喜 $太^{\mathrm{a}}$ 藤原康宏 ${ }^{\mathrm{a}}$, 野間和広 ${ }^{\mathrm{a}}$, 櫻間教文 ${ }^{\mathrm{a}}$

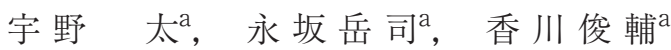
白川靖博 ${ }^{\mathrm{a}}$, 山辻知 樹 ${ }^{\mathrm{a}}$, 小林直 哉 藤原俊義, 羽井佐 実 ${ }^{\mathrm{b}}$, 松岡順治 ${ }^{\mathrm{a}}$ 猶本良夫 ${ }^{\mathrm{a}}$

食道㮩室は比較的稀な疾患で, さらに無症状に経過する ことが多く，手術適応となることは少ない。当科に打いて 経験した食道憩室の手術症例について報告する。1997年 1 月～2009年 12 月の間の食道憩室手術症例は 9 例。発生部位 の内訳は, 咽頭食道憩室 6 例, 胸部食道憩室 3 例であった. 各症例とも術前に何らかの症状を有していた。全例とも術 後 9 例とも術後は術前見られていた嚥下困難などの症状は 改善した。

\section{3. 特異な経過を示した，気管支中心性肉芽腫の 1 手 術例}

川崎医科大学附属川崎病院 外科

岡好仁, 木下真一郎, 林次郎

吉田和弘, 森田一郎

65歳女性，平成21年の検診にて異常陰影（右下葉 S 9 ） を指摘され，9月当院内科で精査されるも悪性所見は認め ず経過観察となる.10/16から発熱・右胸痛・咳を認め, 近 医で治療されるも改善せず, $10 / 23$ 当院内科に入院. 右胸水 増量に伴い呼吸困難を訴え，11/ 2 には右気胸を併発した。 右下葉腫瘤との関連が強く疑われたため, 11/ 5 に手術を施 行した。病理結果は気管支中心性肉芽腫. 術後経過は良好 で，アスペルギルスの精查を施行予定. 


\section{4. 非定型抗酸菌症切除例の検討}

川崎医科大学 胸部心臟血管外科

保田紘一郎, 前田 愛, 湯川拓 郎

平見有二, 清水克彦, 中田昌男

非定型抗酸菌症に対する標準治療は, マクロライド系抗 菌剂と抗結核薬を併用する多剂併用療法が推奨されている が，手術の適応となる症例も存在する. 日本結核学会によ る手術適応は，(1)大量排菌が持続しており，(2)X線所見に しばしば増悪が見られ，(3)病巣が限局性であり，(4)比較的 若年で肺機能から見て手術に耐えうるものとされている. 当院で過去 3 年間に切除術が施行された 4 例について検討 し報告する。

\section{5. 腹壁デスモイドの一例}

川崎医科大学附属川崎病院 外科

横田亮，吉田和弘， 木下真一郎

林次郎, 森田一郎

稀である腹壁デスモイドの一例を経験したので報告す る. 症例は 30 歳代男性. 5 年前に他院にて腹腔鏡補助下右 上腹部縦小開腹で胆囊摘出術をうけた。手術痕に一致し腫 脹・疼痛があり当院受診。血液検査で白血球の上昇あり. 腹部 CT, MRI で腹直筋内の肉芽あるいは膿瘍と診断. 穿 刺排膿できず。手術治療を行った。病理検査でデスモイド と診断. 外来経過観察中 10 力月後に再発. 手術にて再切除. 現在外来経過観察中である。

\section{6. 腎後性腎不全をきたし腎瘻を造設した進行乳癌の} 2 例

川崎医科大学 乳腺甲状腺外科

藤井清香, 園尾博司, 椎木 滋雄 齋 藤 互, 太田裕介, 下 登志朗 水藤晶子, 関 真理, 山本 裕 中島一毅, 田中克浩, 紅林淳一

症例 $1 ： 66$ 歳女性. 右乳房の針生検にて浸潤性小葉癌と 診断. 血尿・血清 $\mathrm{Cr}$ 值の上昇を認めた。 $\mathrm{CT}$ で膀胱壁の肥 厚・両側水腎症を認め, 両側腎瘻造設. TUR-BT 行い乳癌 の転移と診断. 症例 2：75歳女性. 急性腎不全のため入院. 左腎瘻造設. CT で後腹膜腫瘍を認め, 針生検で乳癌転移 と診断。右乳房に腫瘤があり, 針生検にて浸潤性小葉癌と 診断. 考察: 乳癌の遠隔転移には, 後腹膜転移を考慮に入 れておく必要がある.

\section{7. 特発性腸間膜静脈硬化症の一例}

岡山労災病院 外科

西川仁士，大村泰之，川崎賢祐 河合 央, 鷲尾一 浩, 西英行 間野正之, 清水信義

78歳女性，主訴は便秘，右下腹部痛．精査にて特発性腸 間膜静脈硬化症による腸閉塞と診断された。腸閉塞症状は 保存的に軽快したが，右下腹部の圧痛が残り，右半結腸切 除術を施行した。盲腸，上行結腸は青色調に変色，硬化し ていた，回結腸静脈と中結腸静脈右枝には血流がみられな かった。病理組織学的には粘膜下の線維化や静脈の石灰化 を認めた．本疾患は比較的稀な疾患であるため，若干の文 献的考察を加えて報告する.

\section{8．交通事故による外傷性心破裂の救命例}

国立病院機構岡山医療センター 心臟血管外科

岡 崎良紀，奥 山 倫 弘，加藤源太郎 越 智 吉 樹，中井 幹三，岡田正比呂

交通事故による高エネルギー外傷はしばしば重篤な状態 に陥る。今回われわれは交通事故による外傷性心破裂の救 命例を経験したので報告する，症例は73歳女性．歩行中に 軽自動車にはねられた後ショック状態に陥り当院に救急搬 送. CTにて心タンポナーデを認めたため緊急開胸術施行 したところ右室自由壁に長さ約 $5 \mathrm{~cm}$ 程度の破裂を認めたた め右室修復し手術終了した。術後経過に大きな問題なく第 45病日で退院となった。

\section{9. 手掌の紅斑と指尖の疼痛を伴った左鎖骨下動脈狭 㩈の 1 例}

岡山労災病院 外科 ${ }^{\mathrm{a}}$, 皮膚科 ${ }^{\mathrm{b}}$

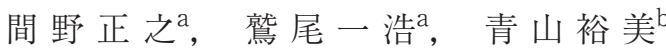
西 英 行 $^{\mathrm{a}}$, 大村泰之 之 $^{\mathrm{a}}$, 河合 央 $^{\mathrm{a}}$ 川崎賢祐 ${ }^{\mathrm{a}}$, 西川仁士 ${ }^{\mathrm{a}}$, 清水信 義 ${ }^{\mathrm{a}}$

症例は54歳女性. 主訴は左指尖の疼痛と手掌の有痛性の 紅斑。血管炎を疑い紅班部の皮虚生検を施行す。病理所見 は毛細血管の動脈内に血栓を認めるも血管炎の所見は見ら れない。指尖脈波は波の鈍化と一部は波高低下を認好，皮 虐温も低下している，左右の上肢の血圧差（28mmHg）を認 め, 造影 CT にて左鎖骨下動脈狭㩁が判明す、ステント内 挿術（EXPRESS）を施行す。術後は抗凝固剂と血小板凝 集抑制剤投与により痛み・紅斑は消失している。 


\section{0. 術後21年間開存している浅大腿動脈 一 足関節部 後脛骨動脈バイパスのバージャー病の 1 例}

川崎医科大学 胸部心臟血管外科

河田敏明，正木久男，田淵篤 柚木靖弘, 濱中荘平, 久保裕司 山澤隆彦, 手島英一, 種本和雄

閉塞動脈疾患の足関節部へのバイパスの開存成績は悪い のが現状である. 今回で, バージャー病で術後 21 年間開存 している浅大腿動脈 一 足関節部後脛骨動脈バイパスの 1 例を経験したので報告する，症例は，30代の女性で，足部 潰瘍を主訴に紹介される，血管造影ではバージャー病の所 見であった。手術は, in situにて左浅大腿動脈 一足関節部 後脛骨動脈バイパスと腰部交感神経切除を併用し，その後 21年目の 3D-CTでも良好に開存していた。

\section{1. ステントグラフト留置術を施行した破裂性胸部大 動脈瘤の 2 症例}

国立病院機構岡山医療センター 教育研修部a, 心臟血管 外科 ${ }^{b}$

大倉隆宏 ${ }^{\mathrm{a}}$, 中井幹三 ${ }^{\mathrm{b}}$, 奥山倫弘 ${ }^{\mathrm{b}}$ 加藤源太郎 ${ }^{\mathrm{b}}$, 越 智 吉 樹 ${ }^{\mathrm{b}}$, 岡田正比呂 ${ }^{\mathrm{b}}$

破裂性胸部大動脈㾯は, 通常, 開胸手術が必要で, 手術 死亡率の高い緊急疾患である。我々は，本症に対してステ ントグラフト留置術を施行し，良好な経過を得た 2 症例を 経験した. 1 例目は83歳女性, 下行大動脈中部の胸部大動 脈瘤. 症例 2 も8歳女性, 腹腔動脈直上の胸部大動脈瘤 (径 $45 \times 55 \mathrm{~mm})$ ．耐術能の低い高齢者は，ステントグラフト治療 の積極的な適応であると考える．若干の文献的考察を加え て報告する。 